\title{
Fostering Students' Cognitive Achievement Through Employing Virtual Reality Laboratory (VRL)
}

\author{
https://doi.org/10.3991/ijoe.v17i13.24529 \\ Dian Ernawati( $\left.{ }^{\bowtie}\right)$, Jaslin Ikhsan \\ Yogyakarta State University, Yogyakarta, Indonesia \\ dianerna15@gmail.com
}

\begin{abstract}
Titration is one of chemistry concepts which highly requires laboratory work in the learning process. However in the implementation, many obstacles are often encountered in a conventional laboratory such as lack of materials, tools, and times which make it less optimal. Evidently these issues could be solved by employing Virtual Reality (VR) technology. Thus far VR makes great contributions especially to the education sector. One of them is through combining it in the process of developing virtual laboratory. Virtual laboratory played an important role in the learning process specifically in terms of laboratory works. It was possible to manipulate 2D (virtual world) objects similar to 3D (real world) objects. This study developed Virtual Reality Laboratory (VRL) to analyze its characteristics, quality, and impact on students' cognitive achievement. A research and development (R\&D) method with a post-test design was applied in this study. The subjects of this study were 102 high school students in class XI. The samples were divided into 3 classes, namely CC (real laboratory); EC-1 (VRL); and EC-2 (real laboratory and VRL). The findings of students' cognitive achievement were analyzed using ANOVA and it was found that there were significant differences in students' cognitive achievement in those three classes. Students who used VRL had higher cognitive achievement than students who used the conventional one. VRL also received excellent grades from chemistry educators. Thus, VRL is very useful as a supplement in the teaching and learning process.
\end{abstract}

Keywords - titration, virtual reality, virtual reality laboratory, cognitive achievement

\section{$1 \quad$ Introduction}

Acid-base titration is one of the chemistry concept considered to be difficult by students [1]-[4]. Acid-base titration demands the students to comprehend acid-base subject matter, along with hydrolysis; and buffer. These three subject matters demand the students to be able to understand the properties of particles in matter, atomic structure, chemical formula and reactions, properties and composition of solutions, ionization and equilibrium [5]. Moreover, the students must also be able to calculate the concentration of a substance that was unknown, $\mathrm{pH}$, volume of solutions, also have an excellent skill 
in drawing and are able to read titration graphs properly. Those skills required for students in the concept of titration certainly make them easy to overcome the misconceptions among students. Misconception in titration happens due to the inadequacy of students' ability to connect the concept of acid-base accurately; confusion regarding the terms in acid-base, inadequacy in terms of the basic understanding about chemistry and inadequacy in terms of the understanding of microscopic form of matter [5].

Based on the problems generally found in learning chemistry such as learning titration concept, the teacher must develop a program that suitable with the objectives of learning chemistry itself. Teachers must construct a program which is applicable with the chemistry learning goal itself. One of them is chemistry teaching that can be implemented through doing experiments in the laboratory. Therefore laboratory has a critical role in chemistry [6], [7]. Theory and practice in chemistry learning must be in line, so that in its implementation, the theory given and laboratory practice must go hand in hand. In this case, the teachers realize that chemistry practice is salient to improve students' knowledge and skills because by doing laboratory work students gain direct experience with the real situation [8]. Laboratory work has become one of the methods to prove scientific theories gained during learning process. The goals of the laboratory work are to apply theories, to acquire scientific attitudes, and to gain skills. Unfortunately, nowadays a lot of schools still arrange separated schedule for both laboratory practice and theoretical study in classroom. Moreover, some of chemistry concepts that highly require laboratory work in the laboratory have not conducted yet. It happens since the number of obstacles at school such as teacher's qualifications, limited amount of time, tools, and materials are frequently encountered. Those exactly become the main reasons triggering lack of laboratory practices [9].

The rapid development of technology in this era has triggered the creation of a virtual laboratory through the use of Virtual Reality (VR) technology. VR is a sophisticated technology that allows users to interact with an existing environment in a virtual world which simulated by a computer. Therefore, the users feel as if they were really immersed in that environment. A recent research findings dealing with the application of VR on education demonstrated that VR-based learning can improve spatial abilities [10]-[12], motivation [13], [14], problem-solving abilities[15], performance [16], and student learning outcomes [17]. VR has been widely used in many scientific studies and received a lot of positive responses. However, in fact the research that reported VR implementation in chemistry, especially in laboratory work has not been conducted yet. Therefore, the research concerning the application of VR in laboratory works of chemistry have to be done so that the data gained could be combined with the previous research and also could be generalized.

VR-based learning includes in the form of games, simulations, or virtual worlds that can be run both on a computer and android platform [18]. The android-based simulation becomes one of the innovative learning methods amongst high-school students. The simulation method in the learning process is believed to bring positive outcome toward students' habits, attitudes, and learning outcomes [19]. The application of VR-based laboratory practice simulation on android in fact enhances critical thinking critical thinking [20], scientific attitude [21], spatial ability [22], and self-confidence [23]. In special cases, VR-based laboratory works of chemistry simulations provide students 
with basic knowledge and experience in the use of tools, materials, and proper laboratory work procedures. Moreover the students are able to conduct laboratory work repeatedly without any concerns such as being contaminated by dangerous chemicals, broken tools, depleted materials, and time limit. Nevertheless, VR-based chemistry practice simulation has not been utilized broadly by teachers and students as an innovative learning medium.

Basically, some previous research on the development and the use of virtual reality laboratories (VRL) in learning already exist such as the development of VRL in studying electrolytes and non-electrolytes material in terms of its effect on students' understanding abilities [24]. In addition, VRL is also developed to study redox material in terms of students' cognitive outcomes [25]. Another research was also developed VRL but with different nomenclature such as $3 \mathrm{D}$ visualization program. The development of $3 \mathrm{D}$ visualization program on chemical bonding material improves students' critical thinking skills and scientific attitudes [21]. However, until now there has been no research dealing with the development of a VRL that specifically discusses acid-base titration materials. Accordingly in this study, the researcher intended to develop a VRL which focuses on acid-base titration materials.

In terms of the learning outcomes, the learning process on the titration material is regarded to be successful if students could master all of the competences provided. Thus the level of understanding of students is very critical since it is closely related to the learning outcomes. The quality of students' material mastery is usually measured by standardized achievement tests [26]. Standardized achievement tests are generally designed to obtain information about students' learning outcomes just after the learning process of a certain chapter has been accomplished [27]. While cognitive learning achievement is the ability possessed by the students as a result of the learning process and can be observed through the performance of the students themselves [28]. On the other hand, cognitive chemistry achievement is a change in student behavior as a result of the chemistry learning process in the cognitive, affective, and psychomotor domains [29]. The cognitive achievement assessment is usually preceded by the measurement of learning outcomes and is given after the achievement indicators of certain material are completed. This cognitive measurement is usually conducted in the form of questions given to the students which are arranged based on the six cognitive domains adopted from Bloom's Taxonomy. The six cognitive domains comprised from the lowest level of complexity are: $\mathrm{C} 1$ which is remembering; $\mathrm{C} 2$ is understanding; $\mathrm{C} 3$ is analyzing; C4 is to apply; C4 is evaluating; and C6 is to create [30]. In this study the importance of students' understanding when using VRL in titration topic is the reason why the importance of cognitive assessment must be investigated.

Therefore, this research initially develops a Virtual Reality Laboratory (VRL) technology, especially on acid-base titration topic. The goal is to achieve the research objective which aims to enhance the student's learning achievement through the use of VRL. Thus, the research questions for this research are outlined as follows:

1. How are the characteristics of VRL?

2. How is the quality of VRL viewed from the chemistry teacher point of view?

3. Are there significant differences between the students who utilize VRL and those who do not in in terms of cognitive achievement? 


\section{$2 \quad$ Method}

This research belonged to the type of research and development which referred to the ADDIE development model coined by Dick and Carry. The ADDIE model consists of five stages that must be carried out sequentially, starting from the analysis, design, development, implementation, and the last stage is the evaluation stage. The subject in this research was eleventh grade of science department, with school criteria as follows:

1. School accreditation is A.

2. The curriculum employed is Kurikulum 2013 Revisi.

3. Chemistry laboratory is available.

4. Each room has LCD and high speed internet access (25MBPs minimum).

5. Students have laptops.

6. Each student has android devices with minimum requirement of OS 5.0 (Lollypop).

7. Students are familiar with technology-based chemistry learning.

8. Chemistry teachers are accustomed to using IT-based learning media in their learning process.

The sampling technique used in this study was cluster random sampling. The determination of class was conducted through analyzing daily test scores in previous chapter with normality and homogeneity test. The result of normality and homogeneity test for the determination of sampling class respectively were sig. 0,337 (XI MIPA 1); sig. 0,864 (XI MIPA 2); and sig. 0,316 (XI MIPA 3). The test results indicated that the class had a homogeneous and normal value distribution. Thus, the next step to determine sampling class was performed through lottery system and the results class XI MIPA 1 was as control class (containing 34 students), XI MIPA 2 was as the Experimental class2 (containing 34 students), and XI MIPA 3 was as the experimental class 3 (containing 34 students). The VRL was specially developed to study acid-base titration concept. The post test of acid-base titration was conducted to obtain students' cognitive achievement data. Student's cognitive achievement post-test consisted of 15 multiple choice and 4 essay questions. The realibilities of cognitive achievement was analyzed by quest programs. The Cronbach's alpha reliabilities for multiple choice was 0,94 and and for essay questions was 0,88 .

\subsection{Research design}

The development procedure in this study was adopted from the ADDIE development model which consists of five stages, starting from analyzing; designing; developing; implementing; and the last namely evaluating. The first stage is called analyzing. At this stage, analyzing literature related to the usage of virtual reality in learning process was completely done. Next, collecting information about conditions and problems that exist in the learning process was conducted by giving out questionnaires to chemistry teachers. The determination of chemical materials was then developed into VRL. The study of Kurikulum 2013 Revisi was conducted to determine the standard of ideal learning process. 
The second step was designing. In this step the determination and construction of acid-base titration practice that was included in the VRL application was completely done. Developing VRL application's storyboard was also done. The drafting of learning media (lesson plan, worksheet, and question sheets) and assessment instrument of product. Then the third step was developing. The construction of content in the form of multi-interactive simulation, visualization of $3 \mathrm{D}$ objects, and practice guide in VRL application was done.

The third stage was development. At this stage, the VRL application was developed by blender software. Blender application was applied to create 3D objects while Unity software was applied to provide interaction between those objects. The final result of VRL application development was under the name extension of ".apk" format that was able to run on the Android platform with the operating system (OS) at least 5.0 or lollipop. It means that android which has an OS below 5.0 cannot run this app. The VRL was then assessed by validators and also reviewers. Later, suggestions from validators and peer reviewers were used to revise the VRL before it was implemented. Product assessment conducted by reviewers (high school chemistry teachers) was used to determine the quality of VRL. The assessment was conducted by five chemistry teachers. Then the next step was readability testing which was conducted by fifteen high school students from grade XII (science class).

The next stage was implementing. This stage was accomplished through implementing VRL at schools. VRL implementation was conducted in Senior High School students of grade XI (science class). Three classes were involved in this study with one class as the control class (CC) and two classes as the experimental class (EC-1 and EC1). The leaning process in this stage lasted for five meetings.

The last stage was evaluating. In this stage, the re-assessment was conducted from the analysis stage up to the implementation stage of VRL application development to draw the conclusion of the product's advisability. In this step, quality assessment by educators was also conducted. Students didn't conduct the assessment. They just gave suggestions or feedback toward previous and the latest development of VRL after implementing process. The suggestions or feedback data were applied to develop VRL before it was assessed by instructors. Analyzing assessment results of by the chemistry teachers was then required to judge the product feasibility. Then the product's improvement was employed based on validators, reviewers, and students' sugestions.

\subsection{Data analysis}

Analysis of variance (ANOVA) technique and qualitative description were employed to analyze students' cognitive achievement. While the SPSS-23 application was applied to analyze ANOVA. Quality data of VRL from the reviewers' assessments was analyzed using quantitative description method. Furthermore, the data was then compared to the ideal assessment category [31]. There were five quality categories for media which can be seen in Table 1 . 
Table 1. Ideal rating category

\begin{tabular}{|l|c|}
\hline Score & Quality \\
\hline $\mathrm{Xi}+1,8 \mathrm{SBi}<\overline{\mathrm{x}}$ & Very Good \\
\hline $\mathrm{Xi}+0,6 \mathrm{SBi}<\overline{\mathrm{x}} \leq \mathrm{Xi}+1,8 \mathrm{SBi}$ & Good \\
\hline $\mathrm{Xi}-0,6 \mathrm{SBi}<\overline{\mathrm{x}} \leq \mathrm{Xi}+0,6 \mathrm{SBi}$ & Good Enough \\
\hline $\mathrm{Xi}-1,8 \mathrm{SBi}<\overline{\mathrm{x}} \leq \mathrm{Xi}-0,6 \mathrm{SBi}$ & Poor \\
\hline$\overline{\mathrm{x}} \leq \mathrm{Xi}-1,8 \mathrm{Sbi}$ & Very Poor \\
\hline
\end{tabular}

\section{Method}

\subsection{Developing process}

The advantage of application of virtual reality technology is its ability to provide multi-interactive learning experiences. Therefore the researcher chose blender and unity software to make it easier to develop VRL. In fact blender is the lightest 3D maker software and has a modifier feature [32]. Modifiers are automatic operating systems that can modify objects without changing the basic geometry of the objects. Unfortunately the modifier feature is not possessed by Unity. Therefore it is not surprising that the blender is used as the initial software for designing 3D shapes. The objects created through the use of this application were laboratory rooms, cupboards, tables, stands, clamps, burettes, magnetic stirrers, and indicator solutions. One of the $3 \mathrm{D}$ visualization objects in the blender application can be seen in Figure 1.

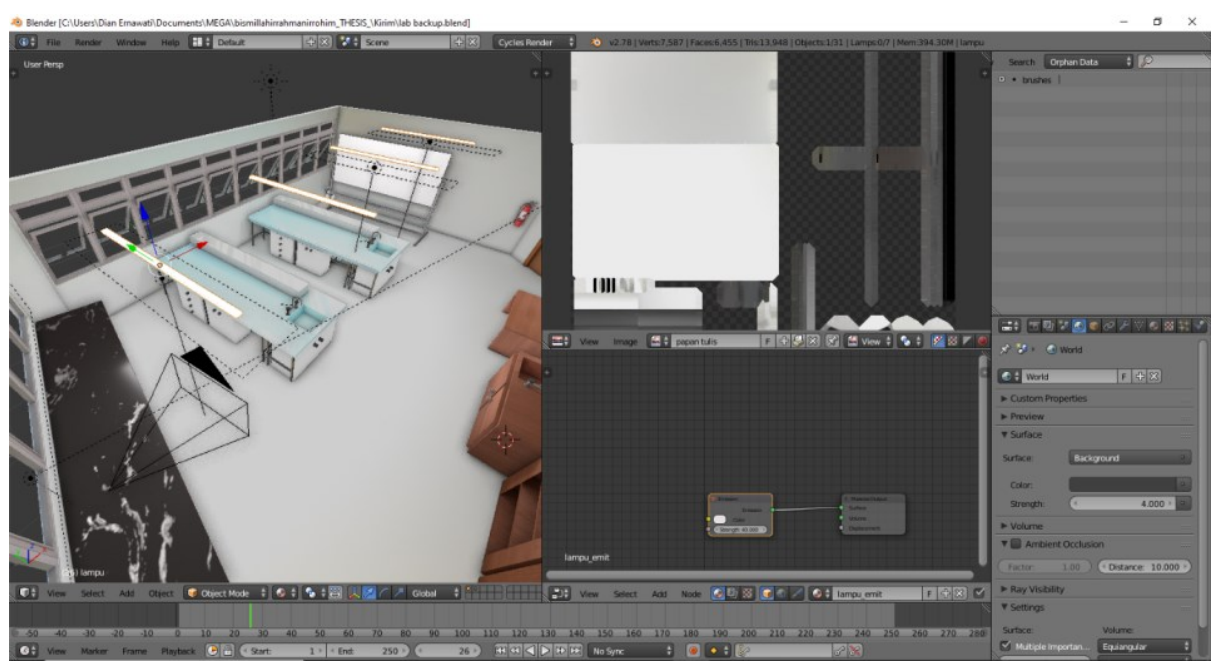

Fig. 1. 3D object visualization in Blender

Next, all 3D objects in Blender were then exported to the Unity program. Unity was chosen as a game engine because it is easy to use and learn. The interaction features in 
Unity are much more comprehensive than in Blender. There is a drag and drop feature. Besides it provides multiple built-in shaders and effects as well as a physics engine and collision detection [33]. On the other hand, the disadvantage of the Unity game engine is that it does not have integrated modeling capabilities. As a result additional applications are required for drawing 3D objects. The best 3D object file formats that can be exported to Unity are under the extension of ".obj" for mesh and ".fbx" for animation [34]. Visualization of VRL in the unity program can be seen in Figure 2.

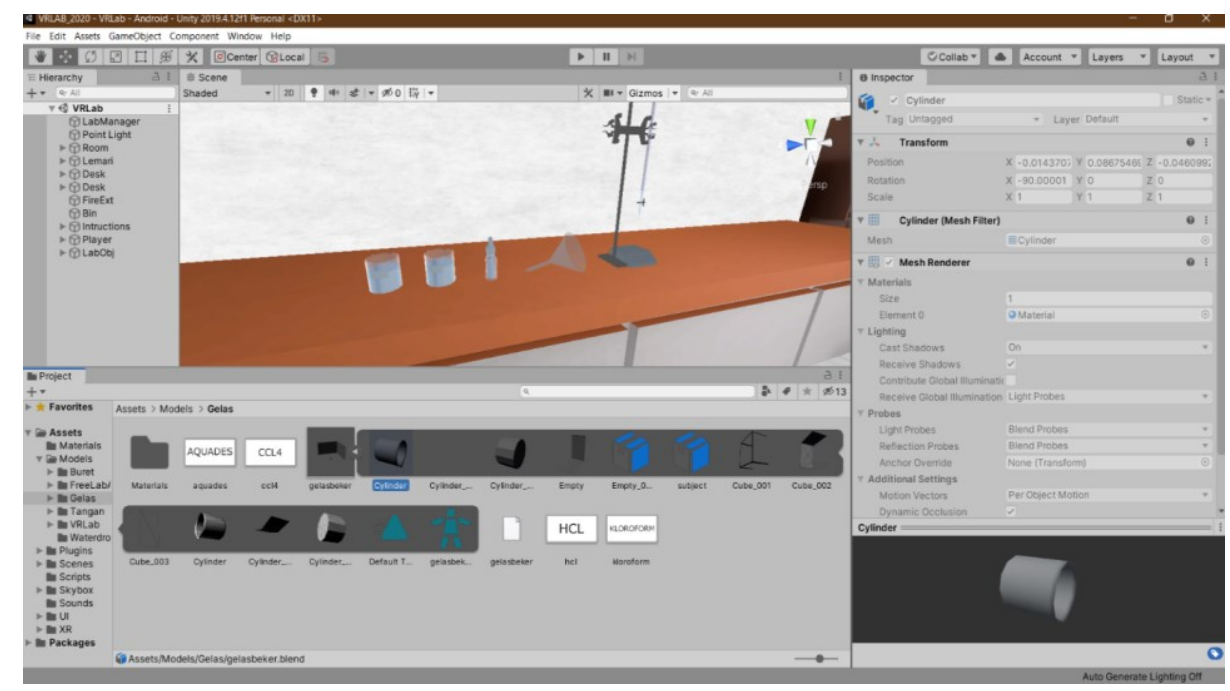

Fig. 2. VRL visualization in unity

The next step is rendering all 3D object assets into an application extension ".apk" format with a file size of $60 \mathrm{MB}$. This application can be run on the android platform. The operating system (OS) that was able to run it at least 5.0 or lollipop. Android which had below 5.0 OS was unable to run the VRL application. In the implementation, VR glasses (Oculus) were highly required and a controller or remote control when run on android. AR-based laboratory view with oculus can be seen in Figure 3.

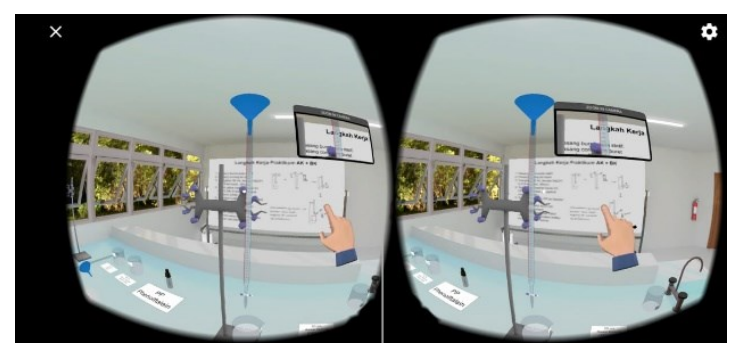

Fig. 3. VRL visualization in Oculus 


\subsection{Learning-game mechanic (LM-GM)}

VRL was a simulation game which allow students did laboratory work independently with fun. As one of educational games, VRL must have learning-game mechanic (LM-GM) to identifying mechanics that can be mapped over to learning outcome. The LM-GM analysis of VRL explained in Table 2 from top to bottom.

Table 2. The analysis based on VRL

\begin{tabular}{|c|c|c|c|}
\hline $\begin{array}{c}\text { Game } \\
\text { Mechanic }\end{array}$ & $\begin{array}{l}\text { Learning } \\
\text { Mechanic }\end{array}$ & Implementation & Usage \\
\hline Cut Scene & Instructional & Pre-render video & $\begin{array}{l}\text { Introduction: tells about a player who entering la- } \\
\text { boratory to do laboratory work. }\end{array}$ \\
\hline Tutorials & Guidance tutorials & Gameplay & $\begin{array}{l}\text { Explained the game-rule, VR googles, and control- } \\
\text { ler' function through scene. }\end{array}$ \\
\hline \multirow{3}{*}{$\begin{array}{l}\text { Selecting/ } \\
\text { collecting }\end{array}$} & \multirow{3}{*}{ Activity } & Collecting item & Matching between name and titration tools. \\
\hline & & Point & scoring reinforce the sense of understanding \\
\hline & & $\begin{array}{l}\text { Laboratory work } \\
\text { procedure on white } \\
\text { board }\end{array}$ & To provide an overview of acid-base practice \\
\hline Movement & Action & $\begin{array}{l}\text { Designing laboratory } \\
\text { work }\end{array}$ & Students did titration experiment \\
\hline Feedback & Feedback & Point & scoring reinforce the sense of understanding \\
\hline $\begin{array}{l}\text { Behavioral } \\
\text { momentum }\end{array}$ & Repetition & Different table & Try another laboratory work with same procedure. \\
\hline
\end{tabular}

The purpose and activity in VRL was all of explain through videos and short scenes. In VRL there were two quests that must be completed by students. They will be given point by completing the quest. The first quest was "Matching". This quest about the introduction of tools and materials used by students during laboratory work. The quest asked students to determine the name and function of the tools and materials in the laboratory. If the student was correct he will get points, and if not he will not get points. The second quest was "Simulation". This quest asked students did laboratory work according to the instructions in the game. If the student can do the steps correctly then he will get a high point. There were four titration type in the VRL. After students complete one type of titration, they could perform other titration type with same procedure.

\subsection{Game validation}

VRL was validated by 3 experts. They validated the product in terms of content, technique, and learning which was interpreted into 24 indicators. The validation results were analyzed using aiken's V. Based on the results of the analysis, the validity coefficient was 0.85 . This indicated that the product was ready to use through several revisions. The VRL validation sheet was also attached with an input sheet that aimed to improve the quality of the VRL. 


\subsection{Effect of VRL on cognitive achievement}

The VRL implementation aims to measure students' cognitive achievement. The VRL developed was able to improve the students' cognitive achievement. As for the cognitive domain adopted from Bloom's taxonomy (C1-C6) was in accordance with the stages of acid-base titration experiments on the VRL development. In terms of (C1) the seeing stage, when using a virtual reality laboratory, the students observed carefully the tools used, the materials used, of course they were also required to know the names of the tools and materials. In terms of (C2) understanding stage, before carrying out a titration, the students were required to know the function of the tools, materials, steps and titration techniques. In terms of (C3) applying stage, the students were required to conduct acid-base titration experiments by themselves. Whereas in terms of (C4) analyzing stage, observational data (solution volume) that had been obtained from the previous experiment were then analyzed. While in terms of (C5) evaluating stage, the students carried out discussion activities, drew conclusion, and presented the reports on the results of their experimental data analysis. Whereas in terms of (C6) creating stage, the students was able to design acid-base titration tools and was able to describe acidbase titration graphs. Thus, the use of learning media in the form of VRL became one way to improve students' cognitive achievement. The indicators of cognitive achievement questions can be seen in Table 3 .

Table 3. Cognitive achievement indicators

\begin{tabular}{|l|c|c|c|c|c|}
\hline \multirow{2}{*}{\multicolumn{1}{|c|}{ Indicators }} & \multicolumn{4}{c|}{ Multiple choices } & \multirow{2}{*}{ Essay } \\
\cline { 2 - 6 } & $\boldsymbol{C 1}$ & $\boldsymbol{C 2}$ & $\boldsymbol{C 3}$ & $\boldsymbol{C 4 , 5 , 6}$ & \\
\hline Titration component & 1 & & 2 & & 1 (C6) \\
\hline The role of acid-based titration & 8 & & 5 & & \\
\hline Indicators & & 5 & & 10,11 & $2(\mathrm{C} 4), 3(\mathrm{C} 5)$ \\
\hline $\mathrm{pH}$ calculations & & & $12,13,14$, & $6,7,3,9$ & \\
\hline Acid-based titration types & & 4 & & 15 & \\
\hline Titration curves & & & & & $4(\mathrm{C} 6)$ \\
\hline
\end{tabular}

The results of the VRL implementation were the post-test value of cognitive achievement can be seen in Table 4 and the results of ANOVA can be seen in Table 5.

Table 4. Descriptive statistics of cognitive achievement

\begin{tabular}{|l|c|c|c|}
\hline \multicolumn{1}{|c|}{ Class } & N & Mean & SD \\
\hline CC & 34 & 68,18 & 12,686 \\
\hline EC-1 & 34 & 79,85 & 10,765 \\
\hline EC-2 & 34 & 77,50 & 7,940 \\
\hline
\end{tabular}

Table 5. Summary of Anova

\begin{tabular}{|c|c|c|}
\hline F Value & Sig. Value & Conclussion \\
\hline 11,445 & 0,000 & Significantly different \\
\hline
\end{tabular}


Based on Table 4, the data demonstrated that the highest average value of cognitive achievement was obtained by class EC-1, followed by class EC-2. Both classes utilized VRL in the learning process in class. In this case, the use of VRL in the learning process significantly improved students' cognitive achievement. In this situation, it was clearly stated that virtual learning simulation also significantly improved student learning outcomes [35] on both cognitive and non-cognitive achievements [36]. Virtual laboratories also helped the students to increase knowledge, develop skills, facilitate student conceptual change [37], and to make the learning process more effective [38].

Based on the ANOVA findings in Table 5, a significance value of less than 0.05 was obtained. This indicated that there were significant differences in cognitive achievement in each test class. In this study, EC-1 and EC-2 utilizing V-Lab gave better outcomes than the control class. This happened since EC-1 and EC-2 had more learning time duration than CC. CC only took two hours to conduct laboratory works in a conventional laboratory while EC-1 and EC-2 had longer duration since the work conducted online. In addition, due to limited tools and materials, in CC the class was divided into some groups. Some of the students were in charge of conducting the laboratory work, some were taking notes, some were doing the washing up, and some students didn't do anything. Therefore each student within-group did not conduct the laboratory work thoroughly. Unlike in EC-1 and EC-2, these class utilized the VRL and only took about one hour to conduct 3 acid-base titrations experiment. The remaining time in EC-1 and EC-2 was allocated for question-answer activities and drew conclusion. In EC-1 and EC-2, each student did their laboratory work by operating their respective smartphones, so that each student gained the same acid-base titration laboratory work experience even though they had shorter duration. Moreover in the experimental class, students were able to conduct laboratory work anywhere and anytime as long as they had android devices and VR glasses. In addition, laboratory work by using VRL made the students more active and enthusiastic in the learning process [35]. Whereas the students who utilized conventional laboratory got bored and inactive because they were unable to develop their imagination [39].

In addition, the VRL application which was implemented on EC-1 and EC-2 had been designed according to the given theory. Thus, errors that arose during laboratory work due to reading data, turning faucets, or being contaminated by chemical materials were minimized. In the experiment classes, the students within a group were also able to confirm the results of the group member's observation data by doing laboratory work repeatedly by using VRL because the materials and tools provided were sufficient. On the other hand, laboratory work in the conventional laboratories sometimes was not suitable with theory. As a result, the students often misinterpreted the data. Therefore this case EC-1 and EC-2 had higher cognitive achievement than CC. This statement was in line with [40] and [41], the use of technology in learning process such as VRL had a positive influence on the learning experience, scientific attitude, and improving learning outcomes. Practicing using VRL also made students more enthusiastic to take a part in the virtual laboratory than those who conducted laboratory works conventional laboratories which made them bored, less active, and unable to develop their imagination ability [42]. Therefore, it was evidently proven that the use of VRL made 
the cognitive achievement much higher than those who conducted practical work in conventional laboratories.

In terms of the quality of the VRL application, ten chemistry educators were involved to give their feedback on it. The product quality was assessed based on aspects of content, learning, and techniques which were then interpreted into 24 indicators. The description of the VRL quality category for each aspect can be seen in Table 6 .

Table 6. VRL assessment results for each aspect

\begin{tabular}{|l|c|c|c|c|}
\hline \multicolumn{1}{|c|}{ Aspect } & Max Score & Average Score & \% & Category \\
\hline Content & 24 & 22,8 & $95,00 \%$ & Very Good \\
\hline Learning & 36 & 33,8 & $93,88 \%$ & Very Good \\
\hline Technical & 36 & 33,7 & $93,61 \%$ & Very Good \\
\hline All & 96 & 90,3 & $94,06 \%$ & Very Good \\
\hline
\end{tabular}

Based on Table 6 , it was stated that overall the quality of VRL was very good, therefore this product was also suitable as teaching media for educators and sources or student learning supplements. Educators stated that, with virtual laboratories such as the VRL application, students became more active and enthusiastic in the learning process. Moreover students were able to conduct laboratory work anywhere and anytime regardless of place and time [43].

\section{$4 \quad$ Limitation and suggestions for future work}

The limitation of this research and development is that VRL does not yet have audio due to the limitations of Oculus which is not yet equipped with headphone features. Moreover, the VRL product developed in this study can only be operated on Android platform. Other platforms such as IOS and other devices such as computers or PC or laptops still have not been developed yet. In addition in writing observational data during laboratory work or reports is not directly integrated with VRL, as a result the students must write it down on the student worksheet (LKPD) manually. Seeing that the addition of a script for the data input feature in Virtual Reality technology is quite complicated, so this feature has not been included in the VRL. However, the VRL product being developed still does not diminish the essence of the learning objectives to be achieved.

There are some suggestions that can be submitted by the researcher regarding the use of the product. Firstly, VRL can be further applied in Classroom Action Research (CAR). Secondly VRL products can also be applied for experimental research with different research subjects and variables. Thirdly, the VRL requires further research to measure the effectiveness of the VRL on a broader coverage. Another virtual laboratory similar to VRL needs to be developed with more complex and multi-interactive 3D objects in other chemistry concepts whose products can be operated on multi-service and multiplatform. Next, the VRL in learning activities can be utilized by combining it with different methods, models, strategies, and other approaches. And then the VRL must be equipped with a sophisticated VR device which has been equipped with audio 
Paper-Fostering Students' Cognitive Achievement Through Employing Virtual Reality Laboratory...

system as a result the user can experience the sound around the virtual laboratory which make it more real. Finally it is expected that the VRL contains interactive game-based learning in it.

\section{Conclusion}

Based on the findings of the research and development dealing with the VRL application on acid-base titration topic, it can be concluded that VRL contains chemistry laboratory work simulation, especially concerning acid-base titration topic, which is enable the students to conduct experiment anytime and anywhere regardless time and space. The experiments conducted on VRL development design laboratory just like the real one through providing tools and materials, conducting experimental simulations, observing experimental results and then drawing conclusions. The aspects of the scientific method in the development of the VRL are formulating problems, determining hypotheses, conducting experiments, interpreting data and drawing conclusions. In conclusion, the quality of VRL based on the results of the assessment conducted by chemistry teachers is "Very Good" category in terms of the content, learning, and engineering aspects. The experiment classes that utilize VRL in the learning process have more positive impact on cognitive achievement than those utilize the conventional one.

\section{Conflict of interest}

The author declares there No. conflict of interest.

\section{$7 \quad$ Acknowledgement}

The author would like to thank the Directorate of Higher Education, Ministry of Research, Technology and Higher Education, The Republic of Indonesia for funding the research.

\section{$8 \quad$ References}

[1] D. Cros, M. Maurin, R. Amouroux, M. Chastrette, J. Leber, and M. Fayol, "Conceptions of first-year university students of the constituents of matter and the notions of acids and bases," Eur. J. Sci. Educ., vol. 8, no. 3, pp. 305-313, 1986, https://doi.org/10.1080/ $\underline{0140528860080307}$

[2] M. Demerouti, M. Kousathana, and G. Tsaparlis, "Acid-base equilibria, Part I: Upper secondary students"TM misconceptions and difficulties," vol. 3, 2004, Accessed: Apr. 27, 2021. [Online]. Available: https://olympias.lib.uoi.gr/jspui/handle/123456789/8566

[3] D. Rositasari, N. Saridewi, and S. Agung, "Pengembangan tes diagnostik two-tier untuk mendeteksi miskonsepsi siswa SMA pada topik asam-basa," EDUSAINS, vol. 6, no. 2, pp. 169-176, 2015, https://doi.org/10.22219/jinop.v6i1.8445 
Paper-Fostering Students' Cognitive Achievement Through Employing Virtual Reality Laboratory...

[4] B. Ross and H. Munby, "Concept mapping and misconceptions: A study of high-school students' understandings of acids and bases," Int. J. Sci. Educ., vol. 13, no. 1, pp. 11-23, 1991, https://doi.org/10.1080/0950069910130102

[5] K. Sheppard, "High school students' understanding of titrations and related acid-base phenomena," Chem. Educ. Res. Pract., vol. 7, no. 1, pp. 32-45, Jan. 2006, https://doi.org/ $10.1039 / \mathrm{b} 5 \mathrm{rp} 90014 \mathrm{j}$

[6] E. Ristiyani and E. S. Bahriah, "Analisis kesulitan belajar kimia siswa di SMAN X kota Tangerang Selatan,” J. Penelit. dan Pembelajaran IPA, vol. 2, no. 1, p. 18, Jun. 2016, https://doi.org/10.30870/jppi.v2i1.431

[7] L. Yunita, "The learning effectivity of chemistry experimental," JPPI, vol. 3, no. 1, pp. 5364, May 2017, Accessed: Apr. 26, 2021. [Online]. Available: https://www.neliti.com /publications/176919/

[8] I. G. L. Wiratma, "Pengelolaan laboratorium kimia pada SMA Negeri di Kota Singaraja: (Acuan pengembangan model panduan pengelolaan laboratorium kimia berbasis kearifan lokal Tri Sakti)," JPI (Jurnal Pendidik. Indones., vol. 3, no. 2, pp. 2303-288, Jan. 2014, https://doi.org/10.23887/jpi-undiksha.v3i2.4459

[9] Yennita, M. Sukmawati, and Zulirfan, "Hambatan pelaksanaan praktikum IPA fisika yang dihadapi guru SMP Negeri di kota Pekanbaru," J. Pendidik., vol. 3, no. 1, pp. 1-11, 2012, Accessed: Apr. 26, 2021. [Online]. Available: https://jp.ejournal.unri.ac.id/index.php/JP/ article/view/1001

[10] T. J. Barrett, A. T. Stull, T. M. Hsu, and M. Hegarty, "Constrained interactivity for relating multiple representations in science: When virtual is better than real," Comput. Educ., vol. 81, pp. 69-81, Feb. 2015, https://doi.org/10.1016/j.compedu.2014.09.009

[11] E. A. L. Lee and K. W. Wong, "Learning with desktop virtual reality: Low spatial ability learners are more positively affected," Comput. Educ., vol. 79, pp. 49-58, Oct. 2014, https://doi.org/10.1016/j.compedu.2014.07.010

[12] Z. Merchant, E. T. Goetz, W. Keeney-Kennicutt, L. Cifuentes, O. Kwok, and T. J. Davis, "Exploring 3-D virtual reality technology for spatial ability and chemistry achievement," $J$. Comput. Assist. Learn., vol. 29, no. 6, pp. 579-590, Dec. 2013, https://doi.org/10.1111 jical.12018

[13] J. C. Huizenga, G. T. M. ten Dam, J. M. Voogt, and W. F. Admiraal, "Teacher perceptions of the value of game-based learning in secondary education," Comput. Educ., vol. 110, pp. 105-115, Jul. 2017, https://doi.org/10.1016/j.compedu.2017.03.008

[14] X. Xu and F. Ke, "Designing a virtual-reality-based, gamelike math learning environment," Am. J. Distance Educ., vol. 30, no. 1, pp. 27-38, Jan. 2016, https://doi.org/10.1080/ $\underline{08923647.2016 .1119621}$

[15] W. Y. Hwang and S. S. Hu, "Analysis of peer learning behaviors using multiple representations in virtual reality and their impacts on geometry problem solving," Comput. Educ., vol. 62, pp. 308-319, Mar. 2013, https://doi.org/10.1016/j.compedu.2012.10.005

[16] A. T. Stull, T. Barrett, and M. Hegarty, "Usability of concrete and virtual models in chemistry instruction," Comput. Human Behav., vol. 29, no. 6, pp. 2546-2556, Nov. 2013, https://doi.org/10.1016/j.chb.2013.06.012

[17] Z. Merchant, E. T. Goetz, L. Cifuentes, W. Keeney-Kennicutt, and T. J. Davis, "Effectiveness of virtual reality-based instruction on students' learning outcomes in K-12 and higher education: A meta-analysis," Comput. Educ., vol. 70, pp. 29-40, Jan. 2014, https://doi.org/10.1016/j.compedu.2013.07.033

[18] Z. Merchant, E. T. Goetz, W. Keeney-Kennicutt, O. M. Kwok, L. Cifuentes, and T. J. Davis, "The learner characteristics, features of desktop 3D virtual reality environments.; College 
chemistry instruction: A structural equation modeling analysis," Comput. Educ., vol. 59, no. 2, pp. 551-568, Sep. 2012, https://doi.org/10.1016/j.compedu.2012.02.004

[19] D. Vlachopoulos and A. Makri, "The effect of games and simulations on higher education: a systematic literature review," International Journal of Educational Technology in Higher Education, vol. 14, no. 1. Springer Netherlands, pp. 1-33, Dec. 01, 2017, https://doi.org/ 10.1186/s41239-017-0062-1

[20] J. Ikhsan, J. Ikhsan, K. Sugiyarto, and T. Astuti, Fostering student's critical thinking through a virtual reality laboratory. 2020. https://doi.org/10.3991/ijim.v14i08.13069

[21] T. N. Astuti, K. H. Sugiyarto, and J. Ikhsan, "Effect of 3D visualization on students' critical thinking skills and scientific attitude in chemistry," Int. J. Instr., vol. 13, no. 1, pp. 151-164, 2020, https://doi.org/10.29333/iji.2020.13110a

[22] R. Molina-Carmona, M. Pertegal-Felices, A. Jimeno-Morenilla, and H. Mora-Mora, "Virtual Reality Learning Activities for Multimedia Students to Enhance Spatial Ability," Sustainability, vol. 10, no. 4, p. 1074, Apr. 2018, https://doi.org/10.3390/su10041074

[23] D. Ding, W.-P. Brinkman, and M. A. Neerincx, "Simulated thoughts in virtual reality for negotiation training enhance self-efficacy and knowledge," Int. J. Hum. Comput. Stud., vol. 139, p. 102400, Jul. 2020, https://doi.org/10.1016/j.ijhcs.2020.102400

[24] A. Amiati and J. Ikhsan, "The effect of virtual reality laboratory on conceptual understanding in electrolytes and non-electrolytes," J. Educ. Learn., 2019, Accessed: Jul. 04, 2021. [Online]. Available: https://doi.org/10.11591/edulearn.v13i3.13572

[25] J. D. Wijayanti and J. Ikhsan, "Virtual Reality Laboratory for Chemistry Education: The Effect of VR-Lab Media on Student's Cognitive Outcome," 2019. Accessed: Jul. 04, 2021. [Online]. Available: http://seminar.uny.ac.id/sseis/sites/seminar.uny.ac.id.sseis/files/ 2019/C-2 J D Wijayanti.pdf

[26] R. G. Ehrenberg, D. J. Brewer, A. Gamoran, and J. D. Willms, "Class size and student achievement," Psychol. Sci. Public Interes., vol. 2, no. 1, pp. 1-30, May 2001, https://doi.org/10.1111/1529-1006.003

[27] C. R. Reynolds, R. B. Livingston, and V. Willson, Measurement and Assessment in Education. New Jersey: Pearson, 2009.

[28] R. M. Gagne and L. J. Briggs, Principle of instructional design. New York: Holt Rinehart and Winston, 1979.

[29] B. Subali, Prinsip assessment \& evaluasi pembelajaran. Yogyakarta: UNY Press, 2012.

[30] D. R. Krathwohl, "A revision of Bloom's taxonomy: An overview," Theory into Practice, vol. 41, no. 4. Ohio State University Press, pp. 212-218, 2002, https://doi.org/10. 1207/s15430421tip4104 2

[31] S. E. P. Widoyoko, Teknik penyusunan instrumen penilaian. Yogyakarta: Pustaka Pelajar, 2009.

[32] L. Flavell, Beginning Blender: Open Source 3D Modelling, Animation, and Game Design. New York: Spinger, 2021.

[33] R. Gupta, R. Nawani, and V. P., "Virtual Reality Content Creation using Unity 3D and Blender," Int. J. Comput. Appl., vol. 156, no. 3, pp. 8-12, Dec. 2016, https://doi.org/ 10.5120/ijca2016912395

[34] A. Indraprastha and M. Shinozaki, "The Investigation on Using Unity3D Game Engine in Urban Design Study,” ITB J. Inf. Commun. Technol., vol. 3, no. 1, pp. 1-18, 2009, https://doi.org/10.5614/itbj.ict.2009.3.1.1

[35] N. A. Omilani, O. N. M. Rose, and A. S. Abubakar, "The effect of combined virtual and real laboratories on students' achievement in practical chemistry," Int. J. Second. Educ., vol. 4, no. 3, p. 27, 2016, https://doi.org/10.11648/j.ijsedu.20160403.11 
Paper-Fostering Students' Cognitive Achievement Through Employing Virtual Reality Laboratory...

[36] M. Thisgaard and G. Makransky, "Virtual Learning Simulations in High School: Effects on Cognitive and Non-cognitive Outcomes and Implications on the Development of STEM Academic and Career Choice," Front. Psychol., vol. 8, May 2017, https://doi.org/ 10.3389/fpsyg.2017.00805

[37] L. K. Smetana and R. L. Bell, "Computer Simulations to Support Science Instruction and Learning: A critical review of the literature," Int. J. Sci. Educ., vol. 34, no. 9, pp. 13371370, Jun. 2012, https://doi.org/10.1080/09500693.2011.605182

[38] S. Higgins, Z. Xiao, and M. Katsipataki, The impact of digital technology on learning: $A$ summary for the education endowment foundation. Durham: Durham University, 2012.

[39] P. Kim, "Effects of 3D virtual reality of plate tectonics on fifth grade students' achievement and attitude toward science," Interact. Learn. Environ., vol. 14, no. 1, pp. 25-34, Apr. 2006, https://doi.org/10.1080/10494820600697687

[40] K. K. Jabbour, "An Analysis of the Effect of Mobile Learning on Lebanese Higher Education," Informatics Educ., vol. 13, no. 1, pp. 1-15, Apr. 2014, doi: 10.15388/infedu. 2014.01.

[41] C. Tüysüz, "The effect of the virtual laboratory on students' achievement and attitude in chemistry,” Int. Online J. Educ. Sci., vol. 2, no. 1, pp. 37-53, 2010, Accessed: Apr. 26, 2021. [Online]. Available: http://www.iojes.net

[42] M. Ikhsan and Afdal, "Kajian motivasi belajar siswa dalam pembelajaran kimia menggunakan virtual lab," J. Pendas Mahakam, vol. 1, no. 1, pp. 65-68, Jun. 2016, Accessed: Apr. 28, 2021. [Online]. Available: https://jurnal.fkip-uwgm.ac.id/index.php/ pendasmahakam/article/view/43

[43] R. Wijayanti, K. H. Sugiyarto, and J. Ikhsan, "Effectiveness of using virtual chemistry laboratory integrated hybrid learning to students' learning achievement," J. Phys. Conf. Ser., vol. 1156, p. 012031, Jan. 2019, https://doi.org/10.1088/1742-6596/1156/1/012031

\section{Authors}

Dian Ernawati Holds S.Pd (Bachelor of Education) in the Chemistry Education from Yogyakarta State University. Her interest is educational media development as learning innovation, quantitative research in education including implementation of various chemistry teaching-learning in the chemistry classroom.

Jaslin Ikhsan is a lecture and researcher in the Chemistry Department, Faculty of Mathematics and Natural Science, Yogyakarta State University, Indonesia. His interest of researchers in chemistry learning is developing and implementing ICT in the learning activity. The media that have been developed are mobile-based learning media, web-based media, and computer-based media.

Article submitted 2021-06-04. Resubmitted 2021-09-19. Final acceptance 2021-09-20. Final version published as submitted by the authors. 